DOI: $10.17148 / I A R J S E T .2021 .8876$

\title{
Opinion on Services towards Cuisine with Shopping appeals for pilgrims towards Temples in Vellore district
}

\author{
*K. Vidhya ${ }^{1}$, Dr. V. Selvam² \\ Ph. D Full Time Research Scholar, Department of Commerce, SSL, VIT, Vellore 632014, Tamil Nadu ${ }^{1}$ \\ Professor, Department of Commerce, SSL, VIT, Vellore 632014, Tamil Nadu²
}

\begin{abstract}
The United Nations World Trade Organization, is pointed out, that the tourism sector is one among the prime industries in terms of providing jobs and foreign revenue from tourists. Basically, Pilgrim tourism will come under the tourist sector. It brings persons from various places that are different in religion and civilization, provides a chance for pilgrims to meet, interact and to understand cultures of the other people. India receives an average of two billion tourists every year including the domestic pilgrims who visit many pilgrim places. A recent report of World Travel and Tourism Council states that Tamil Nadu only receives $21 \%$ of in total tourists' visits in India. This visit promotes the high growth of food and shopping sector in India, which supplies additional job opportunities which increase the quality of products and level of satisfaction in the pilgrim centres. Hotels and shopping malls in Pilgrim zones provide good quality of food and products. But still, there is a prevailing wrong perception found among pilgrims towards price and quality of available products. Pilgrims perception largely varies towards the food served at hotels, amenities provided at staying places and products sold in the centres at tourist places. This empirical study identify the pilgrim's perceptions about food and shopping amenities at Vellore, a city in Tamil Nadu. The study concludes that the hygiene of food products the mean score value is 3.38 , ranked 1 , hygiene and sanitation at shopping centres, mean score value is 3.34 , ranked 1 .
\end{abstract}

Keywords: Pilgrimage, perception, food, shopping behaviour, facilities

\section{INTRODUCTION}

The pilgrim tourism is highly associate and is a part of the India context. It is largely because India is a nation of distinct cultures (Mishra, 2013). This distinct nature fascinates people around the world and moves towards India's cultural heritage. Indian civilization had an impact on this fascination, Indian civilisation ranged over five thousand years. This has been enhanced by successive migrations from diverse religious and cultural geographies around the world. Thus, this cultural past and richness are reflected in the architectural magnificence of India (Bandyopathy et al., 2008). All these are attractive features in the Indian tourism sector. This tourism is a service-oriented industry, thus the major product presented by tourism sector is hospitality and experience. (Kumar, 2010 and Dasgupta, 2011). Moreover, this tourism industry is one of the prime sectors of earning for India (Ganesh, 2014). Tourism promotes socioeconomic progress by creating job opportunities, expansion of project, infrastructures, and revenue generation. The planning commission of India acknowledged tourism as the second leading sector in providing employment especially for low-skilled employees in the country (MOT, 2012). The pilgrim tourism one of the integral parts of Indian tourism is active enough to attract people. Sripuram Golden Temple, Vellore, Arunachaleshwara temple, Thiruvanamalai and Kanchipuram Perumal temple are well known holy religious and spiritual centre in and around Vellore city, Tamilnadu. The tourists who visit these places registers that the pilgrim visit is a rare chance to visit and pay homage to the Almighty and also to perform necessary religious rituals. Tourists' visits to these places provide a chance to understand and feel the spirituality, to get rid of tension, frustration and stress. This turned as a motivation for consistent tourists flow to such destination by religious and spirituality lovers.

\section{Concept of Tourism}

World Trade Organisation (WTO) defines a tourist as a "temporary visitor staying at least 24 hours in the country/place visited and the purpose of whose journey is either leisure or business". It is tough to describe tourism because it is vastly complicated, and an amalgamation of a variety of factors. The factors like human emotions, desires, and feelings, pull built upon the natural as well as developed resources, transport, accommodation and other related services, the government policy and framework regulations are the factors of tourism. (Holden, 2000) Tourism product can be stated as "a destination of man-made and natural destination services and goods that are likely to induce people to visit a particular country". 


\section{Growth of Tourism Sector in India}

According to the WTTC (World Travel and Tourism Co-operation) report the impact of the tourism industry on the economy (Gross Domestic Product) reaches around Rs.1, 919.70 billion with 2 percent to Rs.4, 360.60 billion, 2.1 per cent of GDP in 2023. The report shows that tourism is fast-growing industries contribute much to the Indian economy. Domestic tourism provides a way for individuals from different places, locales, and civilizations meet one another and share things. Through pilgrimage tourism, domestic tourists experience the richness of their nation and locality. They visit such far places in their nation through pilgrim tourism or otherwise they never visited. Foreign tourists visit places to understand and experience the new kind of heritage and civilization to the nations has numerous and vivid cultures like in India. However, Pilgrimage tourism, also constructs a feeling of nationalisation and reinforces the message of "Unity in diversity". India at present ranks 34 out of 140 economics in tourism and travel competitiveness. Though the government has introduced the e-visa scheme and made effort to increase India's rank in the 'Ease of Doing Business' index, it is still a long road to becoming a major destination for international tourism. India's tourism GDP in 2018 is $6.7 \%$ rise from 2017 , tourism contributed about $9 \%$ to the country's total GDP, nearly 4.3 crore jobs are generated directly and indirectly, by the Tourism and Travel Industry in 2018. The growth was largely driven by domestic tourism, nearly Rs.11, 518 crores combined state's spending on marketing and publicity for tourism. The report says 1.3 Lakhs total branded room in India in 2017-18 rise to 12\% from 2016-17. Nearly 34.40 crore total passengers were received at 102 airports in 2018-19 a rise of $11.6 \%$. The tourism report says that Karnataka and Tamilnadu have more branded rooms in 2018. Delhi has the highest density, rooms per sq km, of branded rooms, followed by Goa. The densest road network is in Delhi, followed by Kerala and Goa, the densest rail network is in Delhi followed by West Bengal and Bihar.

\section{Domestic and Foreign Pilgrim Tourists Arrival Report}

The data relating to domestic and foreign pilgrim tourists arrival report were presented in table 1 .

Table 1- Arrival of Tourists

\begin{tabular}{|c|c|c|}
\hline Year & Domestic tourist & Foreign tourists \\
\hline 2013 & $90,54,286$ & 91,761 \\
\hline 2014 & $1,02,62,671$ & 89,326 \\
\hline 2015 & $1,01,84,667$ & 92,842 \\
\hline 2016 & $1,24,65,204$ & $1,22,011$ \\
\hline 2017 & $1,56,16,974$ & $2,17,314$ \\
\hline 2018 & $2,09,14,415$ & $2,44,182$ \\
\hline 2019 & $49,50,00,000$ & $68,70,000$ \\
\hline
\end{tabular}

Source: http://www.tn.gov.in/

Table 1 shows the figure for domestic and foreign tourist's arrival from 2013 -2018. In 2013 the domestic tourist were 90,54,286 and foreign tourists were 91,761 and in 2016 domestic were 1,24,65,204 and 1,22,011 foreign tourists. In 2018 the domestic tourist arrival is $2,09,14,415$ and foreign tourists arrival to 2,44,182. The arrival of foreign tourists to India is significantly increasing. In addition, the tourist's arrivals from other countries to the top 5 states in India were also presented in the graph.

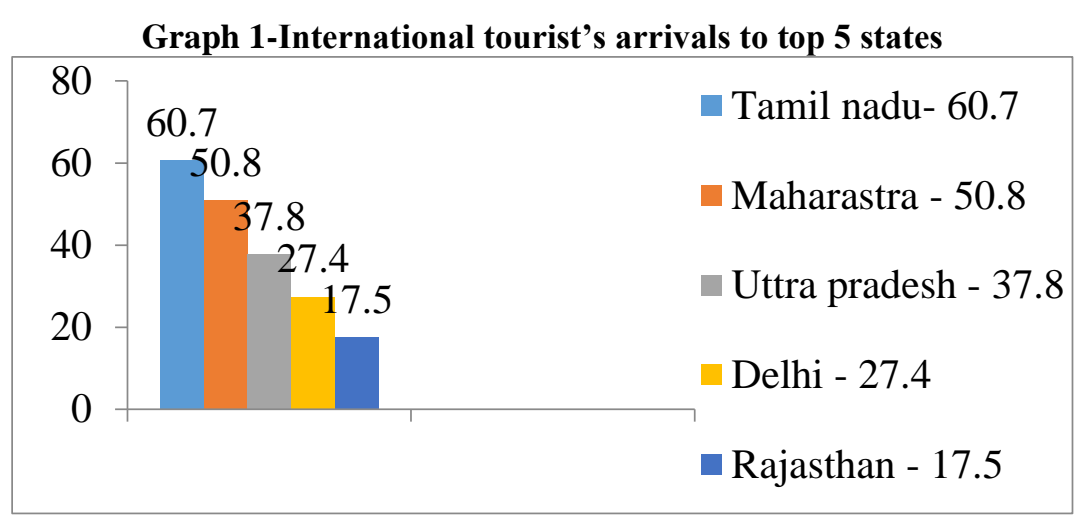

Source: World Travel and Tourism Council 2019

Graph 1, interprets the international tourist's arrival to the top 5 states of India in the year 2019. The X axis shows state wise report and y axis shows percentage of the states. The first highest state with more foreign tourist arrival is Tamilnadu with $60.7 \%$, second is Maharashtra with 50.8\%, third stands Uttar Pradesh with 37.8\%, fourth comes Delhi with $27.4 \%$ and at last Rajasthan with $17.5 \%$. It is a crystal clear to see that, among other important states in India, 


\section{DOI: 10.17148/IARJSET.2021.8876}

Tamilnadu seems to be the best and attracted tourism centre for foreigners in India. Table 2 also presented below for the top five states branded the number of available hotel luxuries rooms in India in 2018 respectively.

Table 2- Top 5 states for branded room

\begin{tabular}{|l|c|}
\hline \multicolumn{1}{|c|}{ States } & No. of Rooms \\
\hline Maharashtra & 23,502 \\
\hline Karnataka & 16,434 \\
\hline Delhi & 14,859 \\
\hline Tamil Nadu & 12,534 \\
\hline Rajasthan & 9,123 \\
\hline
\end{tabular}

Source: World Travel and Tourism Council 2019

Table 2 is projecting that, the first highest state is Maharashtra with 23,502 rooms, Karnataka with 16,434 rooms, Delhi with 14,859 rooms, then Tamilnadu with 12,534 rooms and Rajasthan with 9,123 rooms.

\section{Review of Literature}

The review of literature is selected related to food and shopping attraction, the review was collected from various sources like national, international refereed journals, newspapers, magazines, and websites are presented below.

Ahmed (1991) study reflects that tourist's perception is significant to successful destination marketing because they strongly influence the selection of a destination. Amitabh Mishra (2017) stated that the most important criteria for dissatisfaction of tourists are sanitation at the destination. The study stated that hotel stay, shopping, food and beverages in the market are dirty and unhygienic, the tariff of water and electricity are high, leads to dissatisfaction of majority of the tourists. Aidebert (2011) analysed that each individual, the reality is totally a personal phenomenon, based on that person's needs, wants, values and personal experiences. Dolnlcar (2002) examined the pilgrimage tourists. The study underlines that pilgrim tourists are educated, stay longer, spend more pilgrim crafts and spend more than any other category of tourists. Such tourists travel longer distances than most tourists, they tend to include women and senior people who are interested in the pilgrimage tourism. Foo and Rossetto (1998) pointed out that pilgrimage tourists can either be 'specific' or 'general'. For the former, the primary motivation for travelling is to experience the pilgrimage of a particular destination. The latter type of pilgrimage tourists considers pilgrim as a secondary motivation for travelling. The tourism products are complex in structure and are based on the wise use of the pilgrim and natural resources of the destination.

According to Lambert (2011), tourists with a special interest in pilgrimage belong to the segment of pilgrimage tourism. The research refers to pilgrimage tourism as a visit to pilgrim centres or places such as temples, archaeological and heritage sites away from home. Mediik and Middleton (1973) stated that the tourist's perception is influenced by a total of five components of the tourism product. These are attractions, facilities, accessibility, images, and the price at a tourist destination. Neela Bedrie and Andrew Joseph (2009) found that the presence of microbial pathogens could or will pose a potential health concern to the consuming public. The study mentions that effective way of communication on food risks, the procedure for handling the food with proper instruction and supervision, education for vendor/consumer on the transmission of food borne and food safety risks, how to cook safely and serve foods and proper monitoring the food by food inspectors and controlling authorities by doing this the issues relating food borne disease can be controlled. Muinde and Kurian (2005) identified that sanitary and hygiene practice is the main problem for the food industry both in serving and preparing the food there are unhygienic issues. To emphasize these issues the public health officers were empowered by the city council to provide training on hygiene, sanitation for the street food vendors.

Reisinger and Turner (2003) pointed out that perception may be positive or negative and it differs in intensity. Developing positive perceptions is challenging because perceptions are shaped by a combination of several interacting environments factors. Positive/favourable or negative/unfavourable perception about the destination results in satisfaction or dissatisfaction of tourists. Moufakkir (2008) argued that perception encompasses all the activities dedicated to the satisfaction of tourists' needs. The way a potential tourist perceives the destination influences his/her travel destination choice. Schiff man (2010) stated that the perception represents the process by which meaning is attributed to an object, event or person encountered in the environment. Consumers act and react based on $f$ their perception, not based on objective reality. Sushmi Dey (2019) is discussing that the restaurant and hotel industry should display hygiene ratings on their doors; the reason is to find the complaints and ensure the safety of foods served to raise the standard of dining out and also to check the quality of food.

Times News Network (2019) says that one in four tourists in India visits Tamil Nadu. Tamilnadu saw the most tourists' arrivals despite having one of the lowest expenditure on tourism a study found by the World Travel and Tourism Council - India Initiative. In 2018, India had nearly 2 billion tourists, both domestic and foreign. The report says that nearly 185 crores total tourist visited in 2018, a 12\% increase from 2017. Nearly, 2.89 crore international tourists visit in 2018, up 7\% from 2017. The World Travel and Tourism Council report says that Tamilnadu accounted for $21 \%$ of all tourists visits in 2018 , followed by Uttar Pradesh at $15 \%$. 


\title{
International Advanced Research Journal in Science, Engineering and Technology
}

\author{
Vol. 8, Issue 8, August 2021
}

\section{DOI: 10.17148/IARJSET.2021.8876}

STATEMENT OF THE PROBLEM

Tourism has developed as a significant provider to the Indian economy and contributes much to the Tamilnadu economy. Tamilnadu has many attracting tourism features with different types of available tourism like cultural, rural, medical, pilgrim, and eco-tourism. Vellore tourism zone attracts both domestic and foreign tourists. Based on the review of different literature on the perception of tourists about food and shopping attraction it is inferred that the price, quality, and hygiene of the food served at the place of stay, shopping attractions are less and are not up to the expectation of pilgrims. The researcher would like to analyse the perception of tourists about food, variety, service quality, and behaviour of faculty. The study area covers Vellore disrticit and the places around the zone. The researcher has identified the research gap that there are many researches were done on the satisfaction of tourists but not study was conducted on the tourists' opinion and satisfaction in Vellore region. To fill the research gap, the researcher intends to conduct an empirical study on opinion on services towards cuisine with shopping appeals for pilgrims towards temples in Vellore district.

\section{Objective of the study}

1. To study the demographic profile of the respondents.

2. To find out the opinion and services towards cuisine with shopping appeals for pilgrims towards temples in Vellore district

\section{RESEARCH METHODOLOGY}

The study is empirical in nature and convenience sampling was adopted. The primary data was collected from 100 respondents with the help of well-drafted and pre-tested questionnaire collected from three pilgrim centres namely Golden temple, Jalagandeeswarer temple and Rathinagiri temple from Vellore district of Tamilnadu in administering direct survey method with the help of structured questionnaire containing part 1 as the demographic profile of the respondents and part 2 as the opinion of pilgrim tourist about hotel facilities and shopping attraction having twelve positive statements with five-point Liker't scale from 5 strongly agree to 1 strongly disagree. The primary data was collected through survey method and the secondary data was collected from the period from 1973 to 2020 . The SPSS package version 23 was used for applying statistical tools like percentage analysis, frequency distribution and mean score with rank correlation. The researcher applied the test of reliability and validity. The results of Cronbach's alpha for the study was 0.864 (Hair.et.al 1998) and the content validity test was used by the getting opinion from the subject experts in this field. The major limitation of this study may not universally acceptable if it is conducted in other pilgrim tourist centre of other states in India. The sample size is only 100, if the sample size is more, the results might have differed.

\section{Analysis and Interpretation- I}

Demographic Profile - Percentage Analysis

The demographic profile of pilgrim tourists is depicted in table 3 .

Table 3 Demographic Profile

\begin{tabular}{|c|c|c|c|}
\hline Demographic Profile & Variables & Frequency & Percentage \\
\hline \multirow{3}{*}{ Gender } & Male & 63 & 63 \\
\hline & Female & 37 & 37 \\
\hline & Total & 100 & 100 \\
\hline \multirow{3}{*}{ Marital Status } & Married & 59 & 59 \\
\hline & Unmarried & 41 & 41 \\
\hline & Total & 100 & 100 \\
\hline \multirow{5}{*}{ Age } & 18 to 30 & 36 & 36 \\
\hline & 31 to 43 & 32 & 32 \\
\hline & 44 to 55 & 23 & 23 \\
\hline & Above 55 & 9 & 9 \\
\hline & Total & 100 & 100 \\
\hline \multirow{5}{*}{ Monthly Income } & Below Rs.20,000 & 27 & 27 \\
\hline & Rs. 20,000 to 40,000 & 43 & 43 \\
\hline & Rs. 40,000 to 60,000 & 19 & 19 \\
\hline & Above Rs.60,000 & 11 & 11 \\
\hline & Total & 100 & 100 \\
\hline \multirow{5}{*}{ Education } & Plus 2 & 23 & 23 \\
\hline & Graduate & 41 & 41 \\
\hline & Post Graduate & 28 & 28 \\
\hline & Others & 8 & 8 \\
\hline & Total & 100 & 100 \\
\hline
\end{tabular}


Vol. 8, Issue 8, August 2021

DOI: $10.17148 /$ IARJSET.2021.8876

\begin{tabular}{|c|c|c|c|}
\hline \multirow{8}{*}{ Occupation } & Student & 24 & 24 \\
\hline & Agriculturist & 7 & 7 \\
\hline & Private Employee & 37 & 37 \\
\hline & Entrepreneur & 7 & 7 \\
\hline & Business & 6 & 6 \\
\hline & Self employed & 17 & 17 \\
\hline & Others & 2 & 2 \\
\hline & Total & 100 & 100 \\
\hline \multirow{5}{*}{ State } & Tamil Nadu & 47 & 47 \\
\hline & Karnataka & 19 & 19 \\
\hline & Kerala & 8 & 8 \\
\hline & Andhra Pradesh & 26 & 26 \\
\hline & Total & 100 & 100 \\
\hline \multirow{6}{*}{ Distance from home to pilgrim centres } & Less $150 \mathrm{~km}$ & 28 & 28 \\
\hline & $150-300 \mathrm{~km}$ & 17 & 17 \\
\hline & $300-600 \mathrm{~km}$ & 15 & 15 \\
\hline & $600-900 \mathrm{~km}$ & 16 & 16 \\
\hline & Above 900km & 24 & 24 \\
\hline & Total & 100 & 100 \\
\hline \multirow{4}{*}{ Stay at place of pilgrim } & 1 day & 45 & 45 \\
\hline & 2 to 4 days & 38 & 38 \\
\hline & More than 5 days & 17 & 17 \\
\hline & Total & 100 & 100 \\
\hline \multirow{4}{*}{ Transport used for visiting pilgrim places } & Tourists cars/taxi/bus & 31 & 31 \\
\hline & Own vehicle & 57 & 57 \\
\hline & $\begin{array}{c}\text { Public (local bus/auto } \\
\text { rickshaw) }\end{array}$ & 12 & 12 \\
\hline & Total 100 & 100 & 100 \\
\hline \multirow{5}{*}{ Jointly visiting pilgrim centres } & With Family & 30 & 30 \\
\hline & With Relatives & 23 & 23 \\
\hline & With Friends & 33 & 33 \\
\hline & Others & 14 & 14 \\
\hline & Total & 100 & 100 \\
\hline
\end{tabular}

Source: Primary data

\section{Interpretation}

From the above table 3 , it is inferred that under gender $63 \%$ of the respondents belong to male. Under marital status, $59 \%$ of the respondents belong to the married category. Under the age category, $36 \%$ of the respondents' age is around 18 - 30. Under monthly income $43 \%$ of the respondents' earning range between Rs.20,000 to 40,000. Regarding education $41 \%$ of the respondents belong to the undergraduate category and the occupation; private employees are visiting more comparing with other pilgrim centres by scoring 37\%. Under different states, majority of the pilgrim respondents were from Tamil Nadu, 47\%. Regarding the distance from the home to the place of pilgrim centres, $28 \%$ of the respondents were from less than $150 \mathrm{~km}$ while comparing with other distance and the respondents who stay at the destination for 1 day scored $45 \%$. The pilgrims' major transport mode to visit the destination is their own vehicle which is $57 \%$ and type of group visiting the pilgrim places by accompanying with family is $30 \%$.

\section{Analysis and Interpretation - II}

\section{Opinion of Pilgrim Tourists - Mean Score with Rank Correlation}

The perception of pilgrim tourists about food facilities and shopping attraction was measured with the help of mean score and rank correlation is depicted in table 4. 
Vol. 8, Issue 8, August 2021

DOI: $10.17148 /$ IARJSET.2021.8876

Table 4 Perception of Pilgrim Tourists

\begin{tabular}{|c|c|c|c|c|c|c|c|c|}
\hline Variables & 5 & 4 & 3 & 2 & 1 & Total & $\begin{array}{l}\text { Mean } \\
\text { score }\end{array}$ & Rank \\
\hline \multicolumn{9}{|c|}{ Food facilities } \\
\hline $\begin{array}{l}\text { Variety, taste of food and beverages at the } \\
\text { place of stay }\end{array}$ & 11 & 28 & 40 & 21 & 0 & 100 & 3.29 & 4 \\
\hline $\begin{array}{l}\text { Hygiene of food and beverage at the place of } \\
\text { stay }\end{array}$ & 16 & 27 & 38 & 17 & 2 & 100 & 3.38 & 1 \\
\hline $\begin{array}{l}\text { Prices of food and beverage at the place of } \\
\text { stay }\end{array}$ & 17 & 30 & 23 & 25 & 5 & 100 & 3.33 & 2 \\
\hline $\begin{array}{l}\text { Variety, taste of food' and beverages in and } \\
\text { around tourist spots }\end{array}$ & 13 & 25 & 24 & 27 & 1 & 100 & 3.22 & 5 \\
\hline $\begin{array}{l}\text { Hygiene of food and beverages in and } \\
\text { around tourists spots }\end{array}$ & 9 & 28 & 27 & 27 & 9 & 100 & 3.01 & 6 \\
\hline $\begin{array}{l}\text { Price of food and beverages in and around } \\
\text { tourists spots }\end{array}$ & 12 & 27 & 38 & 24 & 1 & 100 & 3.31 & 3 \\
\hline \multicolumn{9}{|c|}{ Shopping attraction } \\
\hline $\begin{array}{l}\text { Availability of exclusive shopping } \\
\text { attractions }\end{array}$ & 0 & 16 & 37 & 30 & 17 & 100 & 2.51 & 6 \\
\hline Quality of goods purchased & 13 & 25 & 34 & 27 & 1 & 100 & 3.22 & 3 \\
\hline Price of goods & 0 & 16 & 37 & 30 & 17 & 100 & 2.52 & 5 \\
\hline Attitude and behaviour of shopkeepers/staff & 7 & 35 & 39 & 16 & 4 & 100 & 3.28 & 2 \\
\hline Hassel-free shopping/no bargaining & 9 & 27 & 28 & 26 & 10 & 100 & 2.99 & 4 \\
\hline Hygiene and sanitation at shopping centres & 6 & 44 & 28 & 22 & 0 & 100 & 3.34 & 1 \\
\hline
\end{tabular}

Source: Primary data

\section{Interpretation - Hotel Facilities}

From the above table 4, it is inferred that hygiene of food and beverage at the place of stay with mean score value 3.38 was ranked 1, price of food and beverages at the place of stay with mean score value 3.33 was ranked 2, price of food and beverages in and around tourists spots with mean score value 3.31 was ranked 3, variety, the taste of food and beverages at the place of stay with mean score value 3.29 was ranked 4, variety, the taste of food' and beverages in and around tourist spots with mean score value 3.22 was ranked 5 and hygiene of food and beverages in and around tourists spots with mean score value 3.01 was ranked 6.

\section{Interpretation - Shopping Attraction}

From the shopping attraction, it is inferred that hygiene and sanitation at shopping centres with mean score value 3.34 was ranked 1, attitude and behaviour of shopkeepers/staff with mean score value 3.28 was ranked 2, quality of goods purchased with mean score value 3.22 was ranked 3, Hassle-free shopping/no bargaining with mean score value2.99 was ranked 4 , price of goods with mean score value 2.52 was ranked 5 and availability of exclusive shopping attractions with mean score value 2.51 was ranked 6 .

\section{FINDINGS}

1. The majority $(63 \%)$ of the respondents belongs are male.

2. The majority (59\%) of the respondents belongs are married.

3. Out of 100 respondents, 45 respondents stay at the pilgrim centre for one day.

4. Out of 100 respondents, 57 respondents used their own vehicle as to the main mode of transport for visiting pilgrim centre.

5. The major findings of the study on the opinion of pilgrim tourist on the hygiene of food and beverage (27\% agreed) at the place of stay with mean score value 3.38 were ranked 1 and the price of food and beverages (30\% agreed) at the place of stay with mean score value 3.33 was ranked 2. These results show that the pilgrims who visit pilgrim centre were satisfied with the price and hygiene of food and beverage. In relation with shopping attraction, the hygiene and sanitation (44\% agreed) at shopping centres with mean score value 3.34 was ranked 1, attitude and behaviour of shopkeepers/staff (35\% agreed) with mean score value 3.28 was ranked 2. The results on opinion about shopping attraction on hygiene, sanitation and behaviour of shopkeepers were found to be satisfied by all the pilgrims in the study area. 


\section{International Advanced Research Journal in Science, Engineering and Technology}

Vol. 8, Issue 8, August 2021

\section{DOI: 10.17148/IARJSET.2021.8876}

\section{CONCLUSION}

The Indian tourism sector is one among the largest service sectors which have $6.23 \%$ accounts in the total GDP. Vellore city is one of the remarkable pilgrim tourist zones, it attracts tourists from nook and corner of South India. The pilgrims who visit the Golden temple were satisfied with amenities and facilities provided by the authorities and they were felt blessed by Goddess Maha Lakshmi to get good health and wealth. The present study would also provide insights for the planners, administrators, department of travel and tourism and state government officials to take appropriate measures for the promotion of pilgrim tourism by providing more number of good hotels with hygiene, shopping malls, handlooms, handicraft, more number of public transport facilities. And one primary health centre and common service centre (CSC) in the places of Vellore, Kanchipuram and Thiruvannamalai districts should be implemented and particularly in Tamilnadu state so that all the common public will get benefits form the service providers.

\section{REFERENCE}

1. Ahmed Z U (1991), “The Influence of the components of state's Tourists Image on Product Planning Strategy", Tourism Management, Vol. 12 , pp. 331-340

2. Aldebert B, Dang R J and Longhi C (2011), “Innovation in the Tourism Industry: The case of Tourism@”, Tourism Management, Vol. 32, No.5, pp. 1204-1213

3. Amitabh Mishra A (2013) "A Study of the Factors influencing Cultural Tourists' Perception and its Measurement with Reference to Agra", The IUP Journal of Management Research, Vol. 12, No. 4, pp. 42-62.

4. Bandyopadhyay R, Morals D B and Chick G (2008), "Religious and Identity in India's Heritage Tourism", Annals of Tourism Research, Vol.35, No.3, pp. 790-808.

5. Clarke A (2008), "Tourism, Cultures and Heritages: Developing Partnership for a sustainable Future", in the Assembly of European Regions Culture, Education and International Cooperation Committee, Ustron (Silesia), Poland.

6. Dolnicar S (2002), “Activity-Based Market Sub-Segmentation of Cultural mums”, Journal of Hospitality and Tourism Management, Vol.9, No.2, pp. 94-105.

7. Foo L and Rossetto A (1998), "Cultural Tourism in Australia: Characteristics and Motivations", BTR Occasional Paper No. 27, Bureau of Tourism Research, Canberra.

8. Hair J Anderson R Tatham R and Black W (1998) Multivariate Data Analysis, Prentice-Hall International Edition, New Jersey.

9. Holden A (2000), Environmental and Tourism, Routledge, London.

10. Hughes H L (2002), “Cultural and Tourism: A Framework for further Analysis”,Managing Leisure, Vol. 7, No.3, pp. 164-175.

11. Ivanovic M (2008), Cultural Tourism, Juta and Co. Ltd., South Africa.

12. Kantanen T and Tikkanen I (2005), "Advertising in Low and High Involvement Cultural

Cases", Tourism and Hospitality Research, Vol.6.

13. Lambert T S (2011), "Gazing from Home: Cultural Tourism and Art Museums", Annals of Tourism Research, Vol.38, No.2, pp. 403-421

14. Mckercher B (2002), "Towards 3 classification of cultural tourist”, International Journal of Tourism Research, Vol. 4, No. 1, pp. 29-38.

15. Mediik S and Middleton V T C (1973), "Product Formulation in Tourism", Tourism and Marketing, Vol. 13, AIEST, Berne.

16. Mishra A (2013), "A study of the Factors influencing Cultural Tourists' Perception and its Measurement with reference to Agra", The IUP Journal of Marketing Management, Vol. 12, No. 4, pp. 42-64.

17. MOT (2006), Tourism Satellite Accounts for India, 2006

18. MOT (2012), Annual Report 2011-2012, available at Tourism.gov.in/writereaddata/Tender/0517201 21254577, pdf.Accessed on June 16, 2013.

19. Moufakkir, O. (2008). Destination image revisited: The Dutch market perceptions of Morocco as a tourism destination. Tourism development: Growth, myths and inequalities, 85-112.

20. Nella Badrie, Andrew Joseph and Allyson Chen," An observational study of food safety practices by street vendors and microbiological quality of street- purchased hamburger beef patlies in Trinidad, west Indies, Internet Journal of Food Safety, Volume. 3, January $2009,25-31$.

21. Onkvisit S and Shaw J (2009), "International Marketing Strategy and Theory, Routledge, New York.

22. Raina A K and Agarawai S K (2004), The Essence of Tourism Development Star-up and Sons, New Delhi's

23. Reisinger Y and Tuner I (2003), Cross-Cultural Behaviour in Tourism Concept and Analysis, Elsevier Butterworth Heinemann.

24. Schiffman L G, Kanuk L L and Kumar S R (2010), Consumer Behaviour, $10^{\text {th }}$ Edition, Pearson Prentice Hall, New Delhi.

25. Scott J and Selwyn T (2010), Thinking Through Tourism, Berg, New York.

26. Silberberg T (1994), "Cultural Tourism and Business Opportunities for Museums and Heritage Sites", in Quality Management in Urban Tourism: Balancing Business and Environment, Conference of school of business, University of Victoria.

27. Smith 5 L J (1994), "The Tourism Product”, Annals of Tourism Research, Vol. 21, No.3, pp 582-595.

28. Suhmi Dey (2019), "Restaurants will soon have to display hygiene ratings", Saturday September, 7,2019, pp- 11.

29. Timothy DJ and Boyd 5 W (2003), in Bandyopadhyay R (2006), "Representative Dissonance in Heritage Tourism in India", PhD. Thesis, Pennsylvania State University, available at https://etda.libraries.psu.edu/paper/7373/. Accessed in December 4, 2013.

30. Tomlinson J (1991), Cultural Imperialism: A Critical Introduction, Pinter, London.

31. The Times of India (2019) "One in four tourists in India visits Tamil Nadu” December, 14, 2019.

32. Voon B H and Lee N (2009), "Identifying Dimensions of Tourist Satisfaction for a cultural Destination: The case of Longhouses in Sarawak (Borneo)', International Journal of Business and society, Vol. 10, No. 1, pp. 65-82.

33. Williams R (1983), Keywords. A Vocabulary of Culture and Society, Oxford University Press, New York.

34. World Travel and Tourism Council Report 2018. 